[3]

\title{
Impact of land-use change on water resources: Balquhidder catchments
}

\author{
A. Gustard and A.J. Wesselink \\ Institute of Hydrology, Wallingford OXIO 8BB, UK
}

(Received 23 August 1991; revision accepted 9 November 1992)

\begin{abstract}
Gustard, A. and Wesselink, A.J., 1993. Impact of land-use change on water resources: Balquhidder catchments. J. Hydrol., 145: 389-401.

The Institute of Hydrology lumped conceptual model uses rainfall and flow records to optimise a number of parameters controlling interception, soil and channel stores. Land use in the catchment (e.g. heather, grassland and mature forest) is accounted for by using different interception and transpiration rates for different land uses. The model was applied to climate and discharge data from the two Institute of Hydrology experimental catchments at Balquhidder to predict the sensitivity of a number of water resource measures to land-use change. This was achieved by deriving flow duration curves, annual minima series and storage-yield relationships for simulated flow records for varous land-use scenarios. The results are presented in a form which allows the scale of the impact of land-use change on water resources to be estimated for regions of the UK with a similar climate and catchment response to the Balquhidder area.
\end{abstract}

\section{INTRODUCTION}

In recent years a number of process and catchment water balance studies have been undertaken in an attempt to understand the mechanisms of water loss in catchments with various types of vegetation. Of particular interest, from a water resource point of view, is the increase in water loss associated with afforestation that were first indicated by Law (1956), and subsequently confirmed by paired catchment studies in Plynlimon (Kirby et al., 1991). These studies have focused on understanding and modelling evaporation and transpiration processes and estimating the impact of land-use change on the mean flow. Although the implications for water resources have been generalised to other regions of the UK (Newson and Calder, 1989), there have been only a limited number of detailed studies of the water resource implications of land-use change (Calder and Newson, 1979). The paper uses a

Correspondence to: A. Gustard, Institute of Hydrology, Wallingford OX10 8BB, UK. 
conceptual model (Blackie and Eeles, 1985) to simulate time series of daily flows which are then analysed using flow duration curves, annual minimum series and storage-yield relationships. By simulating flows for various landuse scenarios the impact of land-use change on water resources can be estimated.

\section{THE MODEL}

The Institute of Hydrology land-use model (Eeles and Blackie, 1993), was used with each of three dominant land uses - upland pasture, coniferous forest and heather - modelled separately using catchment average values of daily rainfall and evaporation. The first step of the model estimates interception and transpiration loss (Calder and Newson, 1979) to calculate soil moisture storage, effective rainfall available for surface runoff and recharge to soil and groundwater stores. Effective rainfall is distributed into detention storage, and routed as surface runoff to the river channel with a combined delay function, or into soil as groundwater store with a longer delay function. The surface and groundwater flows are summed to give the daily river discharge. Full details of the simulation of daily flows on which this paper is based have been given by Eeles and Blackie (1993), who have described the model components and structure, the input data and the details of the simulation procedure.

Model parameters relating to interception and transpiration, which are dependent on land use, were set by using information from process studies. The remainder, including storage and delay functions, were optimised to give the best fit of modelled to observed runoff for the calibration period.

\section{THE BALQUHIDDER EXPERIMENTAL CATCHMENTS}

The two experimental catchments, Monachyle (predominantly upland pasture and heather) and Kirkton (with a land use of upland pasture, heather and mixed species of coniferous forest) have been described by Johnson and Whitehead (1993). Results of the water balance investigations, which indicate that there have been no significant changes in the water use of either catchment, have been presented by Blackie (1993). A summary of the data used for the calibration of the model are shown in Table 1.

Reliable simultaneous records of runoff and climate data were available for the period April 1984-December 1988, and these were used for model calibration and verification. However, long runoff or rainfall series are not available from the Balquhidder catchmet ts and so historical daily rainfall from the Lochay power station and mean annual Penman potential evapotranspiration 
TABLE 1

Summary of data used for calibration of the model

\begin{tabular}{lcc}
\hline & Monachyle & Kirkton \\
\hline Area $\left(\mathrm{km}^{2}\right)$ & 7.70 & 6.85 \\
$\%$ Upland pasture & 49.6 & 46.1 \\
$\%$ Heather, bilberry & 50.4 & 14.9 \\
\% Coniferous forest & 0.0 & 39.0 \\
Mean flow $\left(\mathrm{m}^{3} \mathrm{~s}^{-1}\right)$ & 0.519 & 0.426 \\
Mean rainfall $\left(\mathrm{mm} \mathrm{year}^{-1}\right)$ & 2755 & 2340 \\
Mean $E_{\mathrm{T}}\left(\mathrm{mm} \mathrm{year}^{-1}\right)$ & 550 & 541 \\
\hline
\end{tabular}

Time series data derived for the period April 1984-December 1988.

$\left(E_{\mathrm{T}}\right)$ were used to generate mean daily flows for the period 1964-1988. The correlation of daily rainfall for both experimental catchments with the Lochay power station gauge for the period 1983-1988 was 0.89. Table 2 shows the observed and simulated flow statistics for both catchments for the period 1984 to 1988 and for the simulated period from 1964 to 1988.

Simulated daily flow series for various land-use combinations were generated for each catchment by altering the relative proportions of forest and

\section{TABLE 2}

Summary of flow statistics for observed (obs.) and simulated (sim.) data

\begin{tabular}{|c|c|c|c|c|c|c|}
\hline & \multicolumn{3}{|l|}{ Monachyle } & \multicolumn{3}{|l|}{ Kirkton } \\
\hline & $\begin{array}{l}\text { Obs., } \\
1984-1988\end{array}$ & $\begin{array}{l}\text { Sim., } \\
\text { 1984-1988 }\end{array}$ & $\begin{array}{l}\text { Sim., } \\
\text { 1964-1988 }\end{array}$ & $\begin{array}{l}\text { Obs., } \\
\text { 1984-1988 }\end{array}$ & $\begin{array}{l}\text { Sim., } \\
\text { 1984-1988 }\end{array}$ & $\begin{array}{l}\text { Sim., } \\
1964-1988\end{array}$ \\
\hline Mean flow $\left(\mathrm{m}^{3} \mathrm{~s}^{-1}\right)$ & 0.517 & 0.525 & 0.404 & 0.418 & 0.402 & 0.298 \\
\hline Flow duration curve & 0.027 & 0.028 & 0.020 & 0.057 & 0.028 & 0.023 \\
\hline$Q 95\left(\mathrm{~m}^{3} \mathrm{~s}^{-1}\right)$ & 0.027 & 0.028 & 0.020 & 0.057 & 0.028 & 0.023 \\
\hline$Q 50\left(\mathrm{~m}^{3} \mathrm{~s}^{-1}\right)$ & 0.192 & 0.251 & 0.188 & 0.243 & 0.209 & 0.150 \\
\hline \multicolumn{7}{|l|}{ Flow frequency curve } \\
\hline MAM $10\left(\mathrm{~m}^{3} \mathrm{~s}^{-1}\right)$ & 0.019 & 0.028 & 0.019 & 0.051 & 0.027 & 0.020 \\
\hline \multicolumn{7}{|c|}{ Storage for given yield and return period of 20 years } \\
\hline Yield $20 \%{ }^{\mathrm{a}}$ & n.a. & n.a. & 2.2 & n.a. & n.a. & 3.3 \\
\hline Yield $50 \%^{\mathrm{a}}$ & n.a. & n.a. & 10.9 & n.a. & n.a. & 16.9 \\
\hline Yield $80 \%^{\mathrm{a}}$ & n.a. & n.a. & 25.6 & n.a. & n.a. & 36.4 \\
\hline
\end{tabular}

${ }^{a}$ Yield as percentage of mean flow for $0 \%$ forest. Storage as percentage of annual average runoff for $0 \%$ forest.

n.a., not applicable. 
TABLE 3

Percentages of upland pasture, heather and forest for model simulations

\begin{tabular}{|c|c|c|c|c|c|}
\hline \multicolumn{3}{|c|}{ Monachyle } & \multicolumn{3}{|l|}{ Kirkton } \\
\hline Pasture & Heather & Forest & Pasture & Heather & Forest \\
\hline 050.4 & 049.6 & 0.0 & 075.6 & 024.4 & 0.0 \\
\hline 0.0 & 0.0 & 100.0 & 0.0 & 0.0 & 100.0 \\
\hline
\end{tabular}

heather/pasture in the simulation model. The ratio of heather to pasture was held constant using a value of 0.98 for Monachyle and 0.32 for Kirkton. A summary of the proportions of each land use is shown in Table 3; more detailed information has been given by Eeles and Blackie (1993). A summary of the simulated flow statistics for the period 1964-1988 is shown in Table 4 for $0 \%$ and $100 \%$ forest cover.

\section{LOW FLOW ANALYSIS}

The measured and simulated daily flow series were analysed using the following procedures described in the Low Flow Studies report (Institute of

TABLE 4

Summary of flow statistics for land-use change simulated over the period 1964-1988

\begin{tabular}{|c|c|c|c|c|}
\hline & \multicolumn{2}{|c|}{ Monachyle } & \multicolumn{2}{|c|}{ Kirkton } \\
\hline & Forest & Cover & Forest & Cover \\
\hline Mean flow $\left(\mathrm{m}^{3} \mathrm{~s}^{-1}\right)$ & 0.404 & 0.315 & 0.325 & 0.248 \\
\hline Flow duration curve & 0.020 & 0.017 & 0.024 & 0.020 \\
\hline$Q 95\left(\mathrm{~m}^{3} \mathrm{~s}^{-1}\right)$ & 0.020 & 0.017 & 0.024 & 0.020 \\
\hline$Q 50\left(\mathrm{~m}^{3} \mathrm{~s}^{-1}\right)$ & 0.188 & 0.130 & 0.165 & 0.121 \\
\hline \multicolumn{5}{|l|}{ Flow frequency curve } \\
\hline $\operatorname{MAM} 10\left(\mathrm{~m}^{3} \mathrm{~s}^{-1}\right)$ & 0.019 & 0.016 & 0.020 & 0.019 \\
\hline \multicolumn{5}{|c|}{ Storage for given vield and return period of 20 vears } \\
\hline Yield $20 \%{ }^{\mathrm{a}}$ & 2.8 & 4.9 & 2.7 & 4.6 \\
\hline Yield $50 \%{ }^{\mathrm{a}}$ & 13.7 & 24.8 & 14.1 & 23.7 \\
\hline Yield $80 \%{ }^{a}$ & 32.0 & 56.3 & 32.0 & 51.1 \\
\hline
\end{tabular}

${ }^{a}$ Yield as percentage of mean flow for $0 \%$ forest. Storage as percentage of annual average runoff for $0 \%$ forest. 




Fig. 1. Monachyle flow duration curves; observed and simulated flows 1984-1988 for actual land use, standardised by observed mean flow $\left(0.517 \mathrm{~m}^{3} \mathrm{~s}^{-1}\right)$.

Hydrology, 1980) for deriving flow duration curves and annual minimum series and by Brown (1991) for deriving storage-yield relationships.

(1) The flow duration curve (Figs. 1-4). This shows the relationship between any given discharge and the percentage of time that the discharge is exceeded. Discharge is plotted on a logarithmic axis with the flow expressed as a percentage of the mean discharge and the frequency plotted using a normal probability scale. Single value low flow indices can be derived from the curve, such as $Q 95$, the flow exceeded for $95 \%$ of the time, or on average for 18 days a year.

(2) Ten day annual minimum series (Figs. 5 and 6). These show the annual minimum 10 day average discharge, expressed as a percentage of the mean flow, plotted against a Weibull reduced variate and return period. Derived from the analysis is the mean of the 10 day annual minimum series (MAM 10).

(3) Storage-yield relationships (Figs. 7 and 8 ) for a 20 year return period of failure. The curves are derived from daily flow series using a behaviour analysis (Brown, 1991) to estimate for a given yield the relationship between the frequency of annual failure and the reservoir storage. By repeating the reservoir simulation for a number of yield values the relationship between reservoir yield, storage and frequency of failure can be derived. The figures show the yield, expressed as a percentage of the mean flow, and the storage volume, expressed as a percentage of total annual runoff, that is required to maintain the yield with a 20 year return period of failure. A constant yield is 


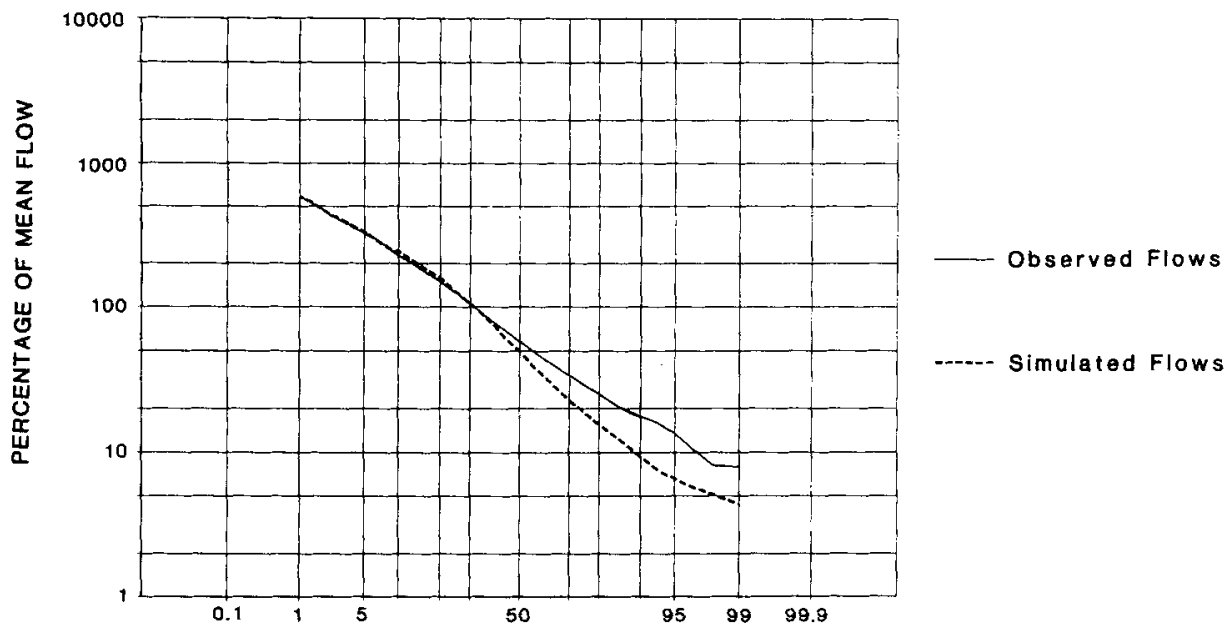

PERCENTAGE OF TIME DISCHARGE EXCEEDED

Fig. 2. Kirkton flow duration curves; observed and simulated flows 1984-1988 for actual land use, standardised by observed mean flow $\left(0.418 \mathrm{~m}^{3} \mathrm{~s}^{-i}\right)$.

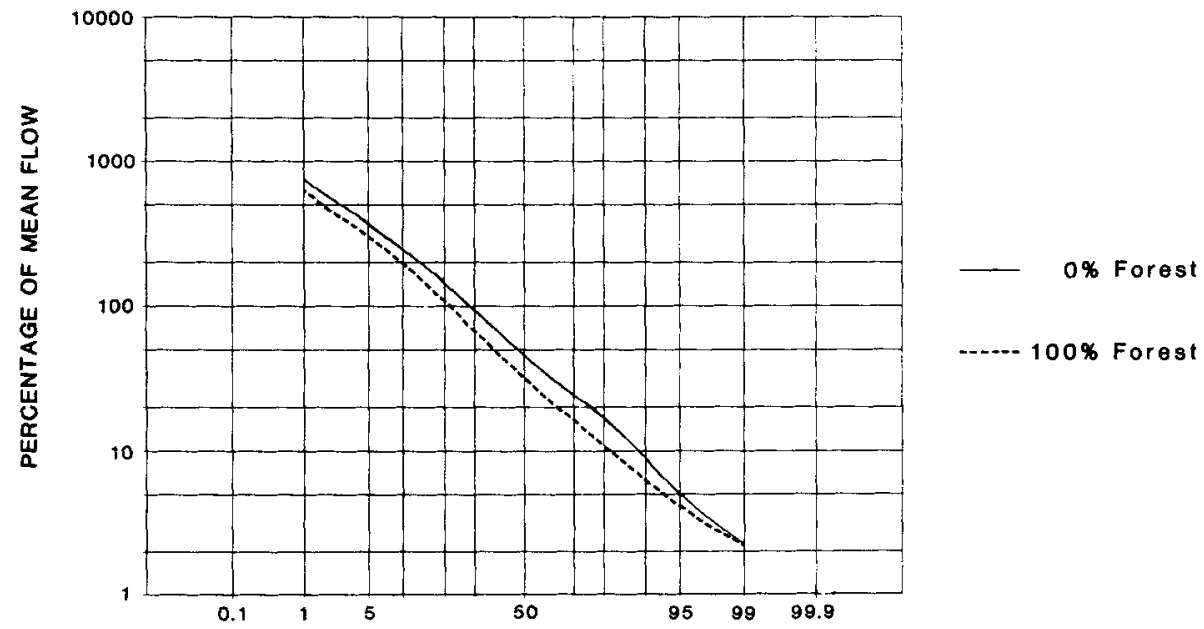

PERCENTAGE OF TIME DISCHARGE EXCEEDED

Fig. 3. Monachyle simulated flow duration curves; $0 \%$ and $100 \%$ forest, $1964-1988$, standardised by mean flow of $0 \%$ forest $\left(0.404 \mathrm{~m}^{3} \mathrm{~s}^{-1}\right)$. 


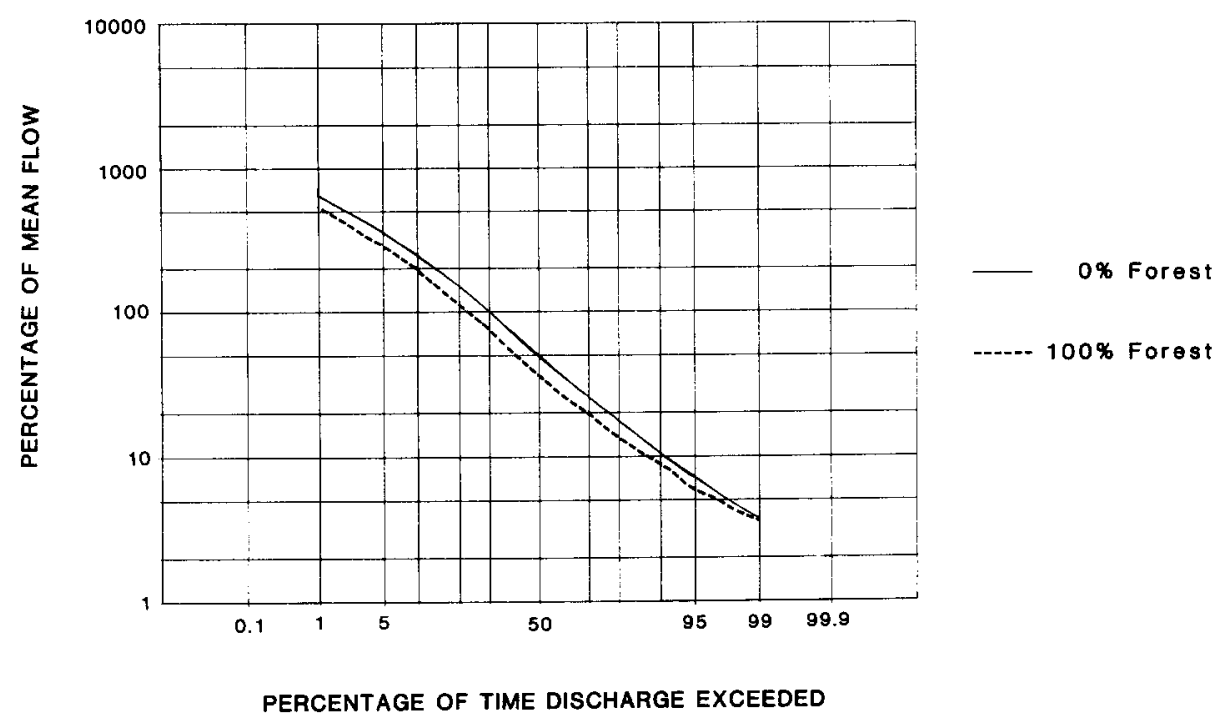

Fig. 4. Kirkton and simulated flow duration curves; $0 \%$ and $100 \%$ forest, 1964-1988, standardised by mean flow of $0 \%$ forest $\left(0.325 \mathrm{~m}^{3} \mathrm{~s}^{-1}\right)$.

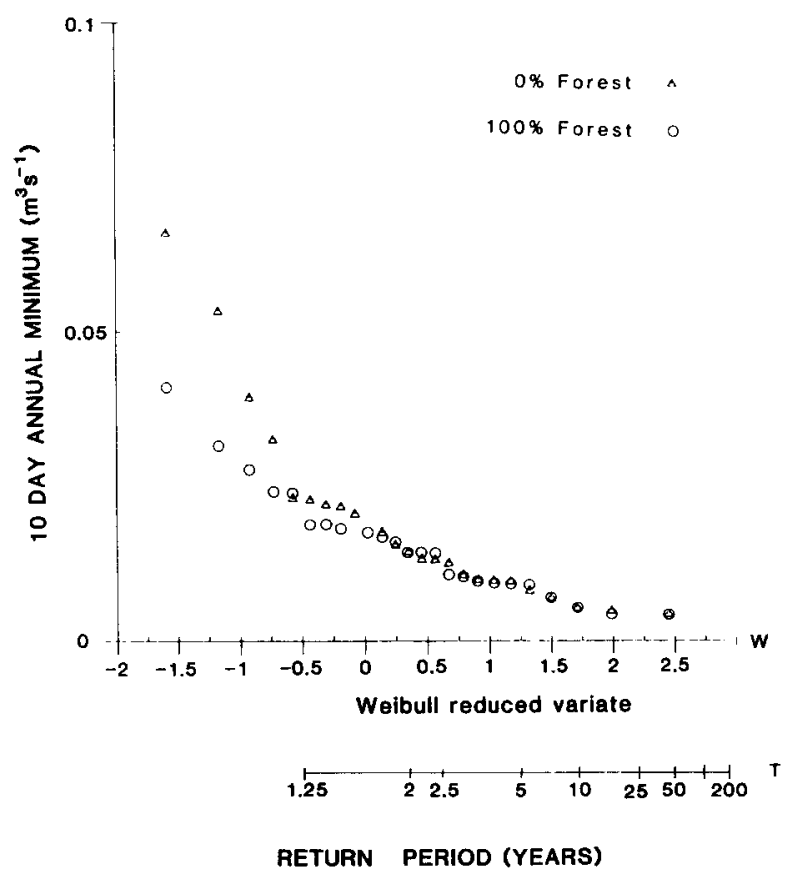

Fig. 5. Monachyle simulated 10 day annual minimum series; $0 \%$ and $100 \%$ forest, $1964-1988$. 

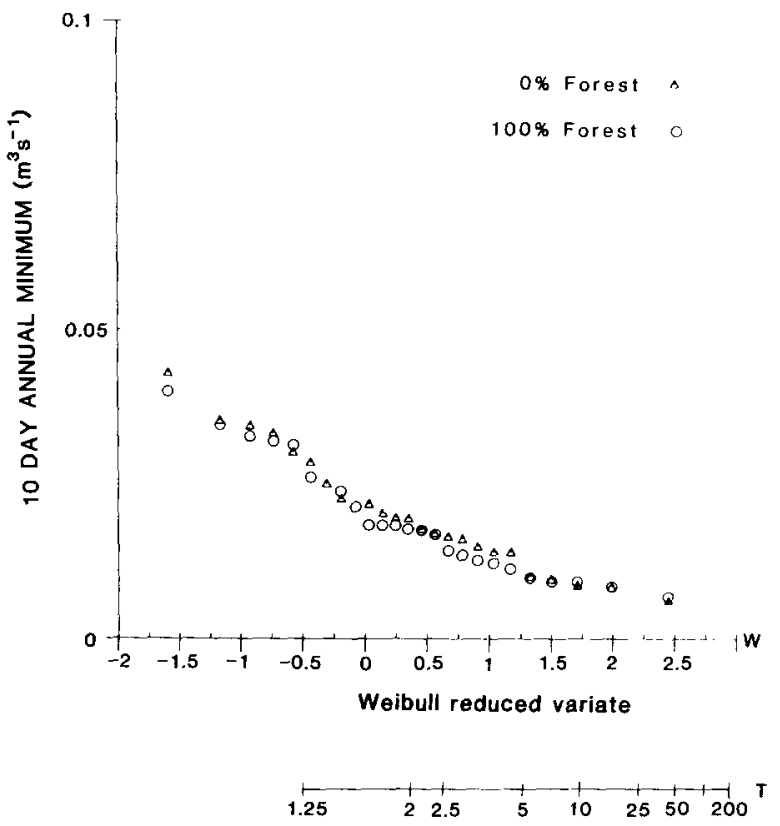

\section{RETURN PERIOD (YEARS)}

Fig. 6. Kirkton simulated 10 day annual minimum series; $0 \%$ and $100 \%$ forest, 1964-1988.

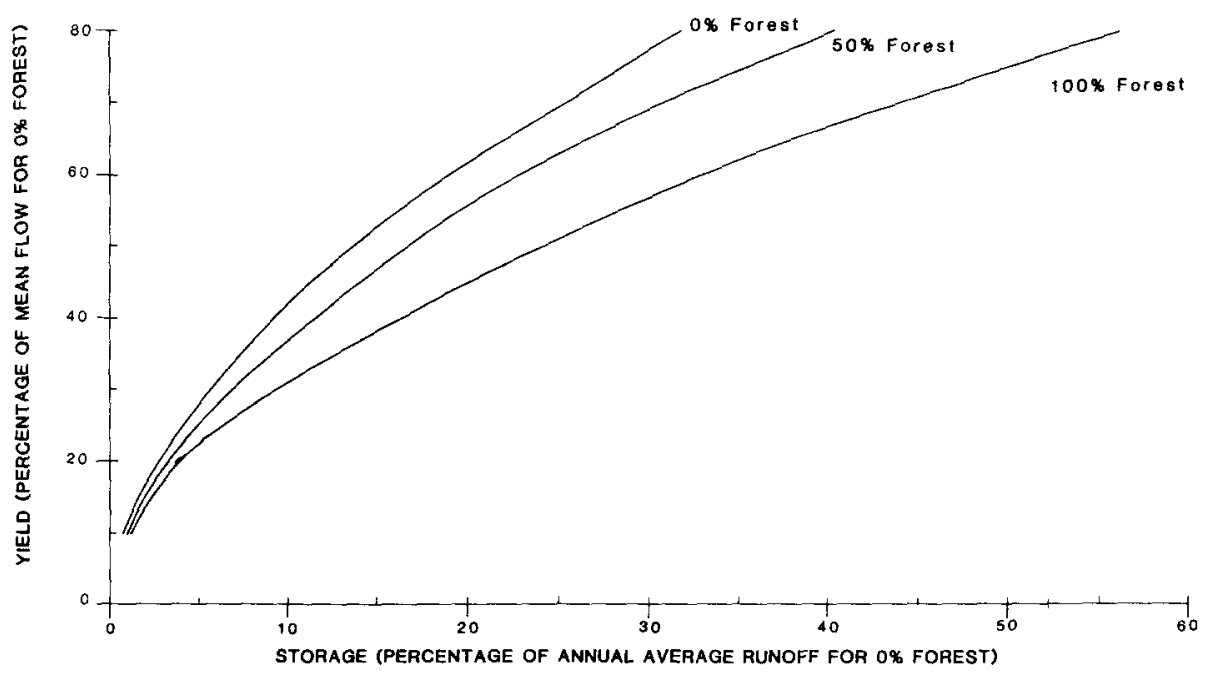

Fig. 7. Monachyle simulated storage-yield diagram; $0 \%$ and $100 \%$ forest, 1964-1988, standardised by mean flow of $0 \%$ forest $\left(0.404 \mathrm{~m}^{3} \mathrm{~s}^{-1}\right)$ and annual average runoff of $0 \%$ forest $\left(12.7 \times 10^{6} \mathrm{~m}^{3}\right)$. 


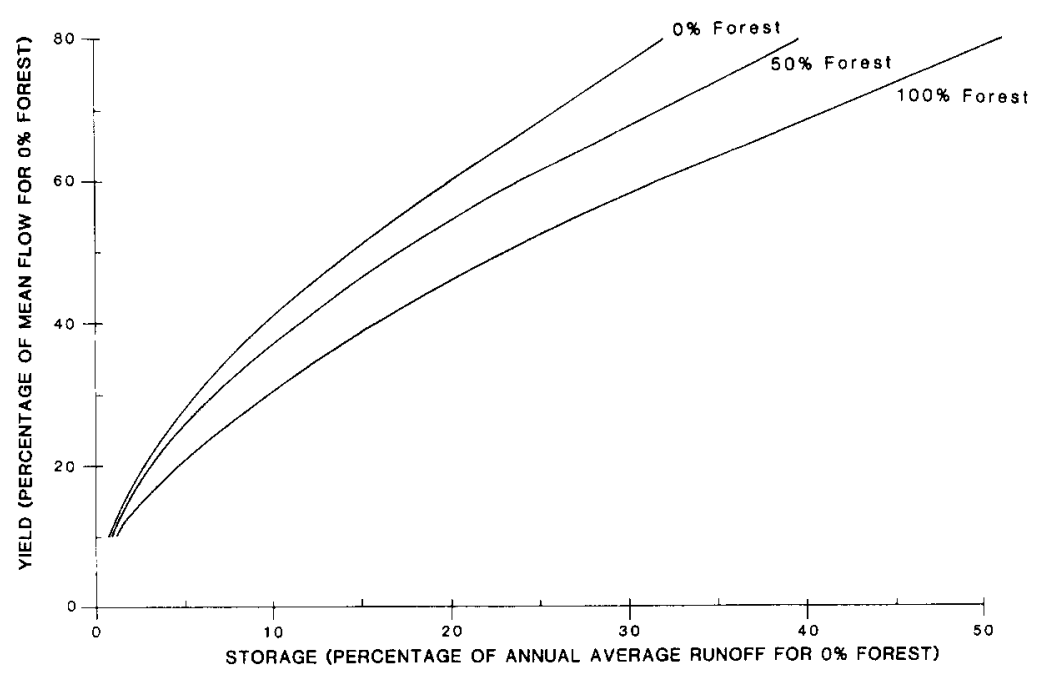

Fig. 8. Kirkton simulated storage-yield diagram; $0 \%$ and $100 \%$ forest, $1964-1988$, standardised by mean flow of $0 \%$ forest $\left(0.325 \mathrm{~m}^{3} \mathrm{~s}^{-1}\right)$ and annual average runoff of $0 \%$ forest $\left(10.2 \times 10^{6} \mathrm{~m}^{3}\right)$.

used in the analysis and the frequency of failure is defined as the average interval in years containing one or more days when the reservoir fails to supply a given yield.

Table 2 summarises the low flow statistics derived from the observed and simulated data. Direct comparisons of the flow statistics between the two catchments do not allow the impact of land-use change to be assessed. This is because comparisons of the water use between the two catchments is of limited significance as a result of the large differences in precipitation between the two catchments, amounting to some $400 \mathrm{~mm}$ per annum, and the differences in Penman potential evaporation (Blackie, 1993). Furthermore, detailed studies of the low flow response of the eight Plynlimon catchments (Kirby et al., 1991) demonstrated that the differences between the subcatchments with the same vegetation, e.g. Tanllwyth and Hore (forested) and Cyff and Gwy (grassland), were as large as the differences between catchments with different vegetation. Differences in low flow response between catchments were more closely related to the presence of minor aquifers in the catchments. To determine the sensitivity of low flows to land-use change it is therefore necessary to model the influence of land-use change on each catchment and then derive low flow statistics from the simulated time series. 


\section{Mean flow}

Comparison of the observed and simulated mean flow with the actual land use (Table 2) shows that the mean of the modelled flows is within $5 \%$ of the observed mean. The mean flow of the simulated records for the longer period is in both catchments lower than for 1984-1988.

The mean flow was determined from the simulated flow records (Table 4) for various proportions of forest. For example, in the Monachyle catchment, the mean flow decreased from 0.404 to $0.315 \mathrm{~m}^{3} \mathrm{~s}^{-1}$, i.e. by $22 \%$, as the proportion of forest in the catchment increases from zero to $100 \%$. In the Kirkton catchment the mean flow decreases from 0.325 to $0.248 \mathrm{~m}^{3} \mathrm{~s}^{-1}$, i.e. by $24 \%$, when the same change in land use is simulated.

\section{Flow duration curves}

Flow duration curves, standardised by the observed mean flow, were produced for observed and simulated flow for the period 1984-1988. For the Monachyle (Fig. 1), flows in excess of the 15 percentile are underestimated by the model, flows between the 15 and 90 percentile are overestimated and lower flows are well predicted. In contrast, for the Kirkton (Fig. 2), there is good agreement for flows in excess of the 40 percentile but lower discharges are underestimated; for example, the estimated 95 percentile is $50 \%$ of the observed value. In evaluating the impact of land-use change, the performance of the model on the two catchments should be considered and it must be remembered that all results are based on simulated data. The results of each of the low flow analyses are therefore presented in the context of a sensitivity analysis of low flow statistics to land-use change and not in terms of predictions of absolute changes.

Flow duration curves were derived for each catchment from the simulated data for the period 1964-1988 for land use with $0 \%$ and $100 \%$ forest. To facilitate comparison of curves between the catchments and with different land use the discharge was standardised by the mean of the simulated flow series for $0 \%$ forest. In both catchments the flow duration curve (Figs. 3 and 4) shifts down with increasing proportion of forest, except at flows below the 99 percentile. Thus, over most frequencies, discharges are predicted to diminish as a result of increasing the proportion of forest on the catchment. For example, the estimated changes (Table 4) are a reduction of $Q 95$ and $Q 50$ from 0.020 to $0.017 \mathrm{~m}^{3} \mathrm{~s}^{-1}$ and from 0.188 to $0.130 \mathrm{~m}^{3} \mathrm{~s}^{-1}$ respectively, in the Monachyle and a reduction of $Q 95$ and $Q 50$ from 0.024 to $0.020 \mathrm{~m}^{3} \mathrm{~s}^{-1}$ and 0.165 to $0.121 \mathrm{~m}^{3} \mathrm{~s}^{-1}$, respectively, in the Kirkton. 


\section{Ten day annual minima series}

The mean of the 4 years of simulated annual 10 day minima (Table 1) is overestimated on the Monachyle and underestimated on the Kirkton catchment. The 10 day annual minima series were plotted for the simulated data with $0 \%$ and $100 \%$ forest (Figs. 5 and 6 ). In the Monachyle and the Kirkton individual annual minima are lower with $100 \%$ forested land use, although the reduction is generally greater for the higher annual minima and is less pronounced on the Kirkton.

\section{Storage-yield relationship}

It is not possible to compare the accuracy of the storage-yield diagram between the simulated and observed data because of the short period of observed data. Figures 7 and 8 present the storage-yield curves for simulated daily flows for the period 1964-1988 for a return period of failure of 20 years. For each catchment, relationships are shown for $0 \%, 50 \%$ and $100 \%$ forest cover. The curves have been standardised using the simulated mean flow for $0 \%$ forest, so that direct comparisons can be made. The yield for a given volume of storage decreases when afforestation increases. For example, the reservoir needed to maintain a yield of $50 \%$ of the average flow in the Monachyle catchment (Fig. 7) with $0 \%$ forest has a volume of $14 \%$ of the mean annual runoff, whereas with $100 \%$ forest the volume required is $25 \%$ of the mean annual runoff. Figure 8 shows a similar sensitivity of the storage-yield relationship to changing land use on the Kirkton catchment.

\section{DISCUSSION}

It is not possible to make direct comparisons of the low flow statistics between the two catchments with different land use because of differences in catchment area, climate and the influence of localised minor aquifers. A sensitivity analysis has therefore been carried out for each catchment. This was achieved by calibrating a conceptual model over the period April 1984December 1988 for each catchment separately. Although short, this period included the notable drought of April-August 1984, when the rainfall was less than $60 \%$ of the 1941-1970 average (Marsh and Lees, 1985). This gives more confidence in the ability of the model to simulate extreme low flows, although the use of mean annual $E_{\mathrm{T}}$ before 1981 may have resulted in an overestimate of low flows in extreme drought years (Eeles and Blackie, 1993).

The sensitivity analysis was carried out by changing the proportions of land uses in the model, while holding the storage and delay functions of the surface 
runoff, soil moisture and groundwater components constant. The observed and simulated output were then analysed using three low flow analysis methods. Although significant differences were found between the observed and modelled flow duration curves on the Kirkton catchment, differences on the Monachyle were much smaller, particularly at the 95 percentile discharge. For the storage-yield analysis high discharges resulting in reservoir refill are as important as the low flows in drought periods; it would therefore not necessarily be appropriate to optimise the conceptual model specifically for improving the low flow response.

The simulation runs of the calibrated model indicate that for both catchments with increasing afforestation: (1) the mean flow decreases; (2) the flow duration curve shifts down; (3) the annual minimum series are lower; (4) the storage needed to maintain a given yield increases. These predictions from the Balquhidder catchments support the general conclusions of earlier investigations carried out on two catchments in Wales and one in the Vosges of France (Gross et al., 1989).

\section{CONCLUSION}

The accuracy of the sensitivity analysis is primarily dependent on the quality of the input data on which the model is calibrated, the simplifications of catchment processes necessarily introduced into the model, and errors introduced using a distant rain gauge and mean monthly $E_{\mathrm{T}}$ values for generating daily flows. In addition, sampling errors are introduced into the low flow analysis particularly when estimating storage-yield relationships for extreme events. Despite these limitations, the results described in the paper are consistent between each of the low flow measures and between the two catchments. In summary, increasing afforestation reduces the discharge for a given frequency of occurrence and increases the reservoir storage required to maintain a given yield. These conclusions suggest that where sufficient data are available for model calibration, the combination of a conceptual model and low flow analysis techniques provide a useful approach for evaluating the impact on water resources of a proposed change in land use.

\section{ACKNOWLEDGEMENT}

The authors acknowledge the work of C.W.O. Eeles, who modelled the observed data from the Balquhidder catchments (Eeles and Blackie, 1993) and produced the simulated flow records analysed in this paper.

\section{REFERENCES}

Blackie, J.R., 1993. The water balance of the Balquhidder catchments. J. Hydrol., 145: 239-257. 
Blackie, J.R. and Eeles, C.W.O., 1985. Lumped catchment models. In: M.G. Anderson and T.P. Burt (Editors), Hydrological Forecasting, Wiley, Chichester, pp. 311-345.

Brown, R.P.C., 1991. Reservoir storage yield analysis using the annual failure method. J. Inst. Water Environ. Manage., 5(2): 116-122.

Calder, I.R., 1986. The influence of land use change on water yield in upland areas of the UK. J. Hydrol., 88: 201-212.

Calder, I.R. and Newson, M.D., 1979, Land use and upland water resources in Britain - a strategic look. Water Resour. Bull., 15(6): 1628-1639.

Eeles, C.W.O. and Blackie, J.R., 1993. Land-use changes in the Balquhidder catchments simulated by a daily streamflow model. J. Hydrol., 145: 315-336.

Gross, R., Eeles, C.W.O. and Gustard, A., 1989. Application of a lumped conceptual model to FRIEND catchments. In: L. Roald, K. Nordsch and K. Anker Hassel (Editors), FRIENDS in Hydrology. IAHS Publ., Wallingford, UK, 187: 309-320.

Institute of Hydrology, 1980. Low Flow Studies Report, No. 1, Institute of Hydrology, Wallingford. IAHS Press, Wallingford, UK, $42 \mathrm{pp}$.

Johnson, R.C. and Whitehead, P.G., 1993. An introduction to the research in the Balquhidder experimental catchments. J. Hydrol., 145: 231-238.

Kirby, C., Newson, M.D. and Gilman, K., 1991. Plynlimon Research: the first two decades. Institute of Hydrology, Wallingford, Rep. 109, $188 \mathrm{pp}$.

Law, F., 1956. The effects of afforestation upon water yields of catchment areas. J. Br. Waterworks Assoc. 38: 484-494.

Marsh, T. and Lees, M.L., 1985. The 1984 Drought. Hydrological Data UK Series. Institute of Hydrology, Wallingford, $82 \mathrm{pp}$.

Newson, M.D. and Calder, I.R., 1989. Forests and water resources: problems of prediction in a regional science. Phil. Trans. R. Soc. London, Ser. B, 324: 283-298. 